\title{
„Jsem jiný, jsem slaný... a umřu dříve“ (dítě/žák s cystickou fibrózou v edukačním prostředí) ${ }^{1}$
}

\author{
Jan Chrastina, Tereza Klvaňová, Bianka Hudcová
}

Univerzita Palackého v Olomouci, Pedagogická fakulta, Ústav speciálněpedagogických studií

Redakci zasláno 15. 2. 2018 / upravená verze obdržena 18. 6. 2018 /

k uveřejnění přijato 18. 6. 2018

\begin{abstract}
Abstrakt: V současném pojetí společného vzdělávání může učitel vykonávat přímou pedagogickou činnost v diverzní společnosti „různých“ žáků. Mezi nimi mohou být rovněž žáci a žákyně s cystickou fibrózou (CF). Jde o nevyléčitelné, progredující a smrtelné onemocnění, které svým nositelům přináší četné zásahy a limitace v každodenních aktivitách, včetně školských. Cílem přehledové studie je analyzovat, popsat a interpretovat vybrané oblasti života dětí, žáků/žákyní a studentů/studentek s tímto onemocněním, které mohou zakládat „jinakost/odlišnost“ v edukačním procesu a prostředí. Metodický rámec byl naplněn analytickou, syntetickou a interpretační činností v podobě monografické procedury založené na rešeršní činnosti zahraničních odborných článků a studií v dostupných databázích. Mezi tematické oblasti, které mohou u osob s CF zakládat ,jinakost/odlišnost“, byla zařazena témata symptomatologie CF, prrístupu okolí (stigma/stigmatizace, viktimizace, postoje okolí apod.), dále subjektivity stavu (prožívání, osobní zkušenosti, strach ze smrti, strach z progrese onemocnění, úzkost, naděje, deprese, resilience, self-efficacy), oblast žáky s CF „Vyžadované“ podpory (psychologické, psychosociální, emoční, vztahové, rodičovské apod.) a rovněž specifika výchovně-vzdělávacího procesu. „Jinakost/odlišnost“ popisovaná v rámci CF spočívá ve specifických potřebách žáků, které vyplývají z př́ípadných změn zdravotního stavu a postojů jejich okolí. Současný stav vzdělávání v našich podmínkách, který respektuje požadavek společného vzdělávání, by měl případné „jinakosti/odlišnosti“ a rozdílnosti „stírat“, a to primárně efektivní pregraduální přípravou učitelů a kontinuálním vzděláváním v této oblasti.
\end{abstract}

Klíčová slova: jinakost/odlišnost, cystická fibróza, limitace, strach, smrt, edukace, psychosociální podpora

1 Př́íspěvek vznikl v rámci řešení projektu Pedagogické fakulty UP v Olomouci (Ústav pro výzkum a vývoj) s názvem Připravenost pracovníků rezidenčních sociálních služeb na zvládání náročné/krizové situace. 


\section{Metodický rámec přípravy, analýzy a sumarizace poznatků}

Text rukopisu vychází z analýzy a kritické interpretace zahraničních studií (zejména odborných článků), jelikož v našich podmínkách je spojitost mezi jinakostí/odlišností a onemocněním cystickou fibrózou řešena pouze okrajově a minimálně. Před zahájením analyticko-syntetické práce s finálním souborem vyhledaných studií (zdrojů) byla formulována klíčová slova a jejich kombinování s Booleovskými operátory: cystic fibrosis, fear, fear of death, fear of progression, anxiety, depression, depress*, dying, school or education or classroom, vicitimization or stigma, well being or life satisfaction, social or psychological support, child or children or pupil or student, other*, otherness, anotherness, distinctness, separateness, recommendation*, teacher*, class or classroom or educat*, limit*, perception, support*

Upřednostněny byly zdroje ne starší 10 let, poté byly zapracovány také zdroje vydané dř́ve, dalším kritériem byla dostupnost studie v podobě fulltextu a pro všechny zdroje poznatků byl dominantním kritériem pro zařazení do finálního souboru textů vztah $\mathrm{k}$ řešenému tématu ( $\mathrm{tj}$. nebyly akceptovány studie odklánějící se od tématu, např. studie zaměřené čistě zdravotnicky, medicínsky, psychologicky a výběrově apod.). Jelikož problematika other(ness) bývá v zahraniční řešena spíše s jinými zdravotními stavy, než je cystická fibróza, došlo také ke studiu tuzemských zdrojů s aplikací východisek v podobě edukačních zkušeností autorů, případně k výběru pouze tematicky souvisejících úseků pasáží odborných textů. Hlavní metodou analýzy dohledaných relevantních poznatků byla tematická analýza. $V$ rámci rešeršní strategie byla stanovena rešeršně významná otázka: Která ze specifik daných př́tomností cystické fibrózy u dětí, žáků a studentů lze považovat za ta, která mohou zakládat u cílové skupiny „jinakost/odlišnost"?

V textu příspěvku označujeme pojmem žák $S C F$ jak žáka s onemocněním, tak žákyni s onemocněním, a hovoříme-li o učiteli, hovoříme o dimenzi jak ženské, tak mužské podoby výkonu této profese. Není-li specifikováno jinak, pak onemocněním automaticky myslíme cystickou fibrózu. 


\section{2 "Jinakost/odlišnost“ a cystická fibróza jako chronické onemocnění}

Jinakost může být chápána jako spojení rozmanitosti a vymezení rozdílů, respektive rozdílností. Jinakost je konstitutivně a neúprosně spojena se stejností (sameness) a se sebou, respektive s vlastním já (self) - žádná konceptualizace jich, respektive oni (they/them) totiž není možná bez konceptualizace stejného a já-my/nás (us) (Cannadine, 2013). Nejčastějšími faktory pro jednotlivce nebo společnost, které mají být srovnávány s určitým druhým (dalším), jsou věk, etnický původ, pohlaví, fyzické schopnosti, rasa, sexuální orientace, sociálně-ekonomický status a další demografické faktory (Gallos \& Ramsey, 1997). Uvádí se, že jinakost zakládá odlišnost; v našich podmínkách nabývá často negativního náboje - hovoří se tak o znevýhodňování na základě jinakosti. Jinakost může být nahlížena také jako mimořádnost, výjimečnost (exceptionality). Tento status může nositele uvést do znevýhodňujícího postavení, prostředí i přístupů. Takto chápaná jinakost zpravidla neumožňuje nositeli prosazování vlastní výjimečnosti ve smyslu výkonnosti, efektivity, „být lepším“. Děti, žáci a studenti s cystickou fibrózou (dále jen CF) neradi dávají najevo to, že jsou jiní/odlišní, že vyžadují jiný/odlišný př́stup, jiné/ odlišné požadavky, jiné/odlišné nároky - zpravidla naopak. V textu nahlížíme na jinakost/jinost jako na cystickou fibrózou daná omezení (limitace), kterými by tato cílová skupina nedisponovala, pokud by neměla toto vzácné, progredující a infaustní onemocnění. Pojem klient/osoba/pacient s infaustním onemocněním jemu samotnému (ale také jeho okolí, společnosti) přináší poznání, že se nejedná jen o nemocného, ale o celý komplex dysfunkcí v sociálních rolích, sociálních pozicích, sociálním fungování a vztazích. To vše je determinováno jeho jinakostí, tj. specifickými potřebami (dysfunkčními), které jsou založeny na změně zdravotního stavu a jsou dány také postoji okolí (rodinného, školního, vrstevnického i širšího sociálního). Předkládaná studie reflektuje dva způsoby nahlížení:

1) respektovat jiné/odlišné, tj. akceptovat specifičnost a autonomii dítěte, žáka, studenta s CF - něco u něj bude jiné/odlišné, ale ne špatné (jinak špatné);

2) apriori nepředpokládat jinakost/odlišnost na základě obav, nejistot, pocitů strachu zainteresovaných osob podílejících se na výchovně-vzdělávacím, rodinném i sociálním systému podpory. 
Jinakost/odlišnost v pojetí významu „být jiný“ může v lidech často vyvolávat pocity strachu, nedůvěry, nepřátelství a mnohdy až odporu. V inkluzivním pojetí vzdělávání bývá konstatováno, že naopak odlišnost je to, co je vítáno, respektováno a zakládá společné vzdělávání bez rozdílností (Adamus, 2015). Předložený text nevychází z tělesné odlišnosti jako jedné z kategorií jinakosti, a to i přesto, že ve speciálněpedagogickém kontextu je s žáky s CF pracováno v somatopedii. V této oblasti je na CF nahlíženo jako na jednu z kategorií omezení hybnosti v podobě onemocnění (dalšími dvěma jsou tělesná postižení a kombinovaná/vícečetná postižení). Současný stav vzdělávání v našich podmínkách, který respektuje společné vzdělávání, by tak měl případné odlišnosti, jinakosti a rozdílnosti „stírat“. Dále na děti, žáky/žákyně a studenty/ studentky s CF (dále jen žák/žáci s CF) nenahlížíme jako na odlišné jedince s viditelnou vadou nebo poruchou či jakýmkoliv zřejmým postižením či znevýhodněním v lidské společnosti, kdy by taková odlišnost (jinakost) byla vždy spojena s řadou specifických problémů (srov. Titzl, 2000, in Slowík, 2007).

Jiný (other) je členem dominantní skupiny (out-group), jeho identita je považována za nedostatečnou a může být diskriminován skupinou (in-group). Pojem othering vymezuje proces transformování difference (rozdílnosti) do pojmu otherness (jinakost), přičemž jeho konstruováním lze rozlišit out-group a in-group skupiny. Samotná jinakost (otherness) je vyjádřením charakteristik jiného (other) (Staszak, 2008). Pojmy jiný (other) a jinakost/ jinost (otherness, př́íp. anotherness) jsou pojmy používané ve společenskovědních a humanitních vědách pro vymezení způsobu, jakým mají lidé tendenci nahlížet na další lidi, kteří jsou „odlišní“ nebo „oddělení od“ (separated) (Dogan, 2000). Na toto rozlišení v textu pohlížíme jako na výrazy obecné, tj. významově neutrálně používané, nikoliv v podobě možných předpokladů, kterými by mohlo docházet $\mathrm{k}$ devalvování osobnosti a jedinečnosti člověka na základě jeho nebo její jinakosti/odlišnosti. Jde o situaci, v níž jsou žáci a žákyně s CF vzděláváni v jedné skupině (školní i sociální), ve které jsou vytvořeny a vytvářeny vztahy, skupinová dynamika a další atributy sociální skupiny, jejichž nositeli jsou žáci (tj. žáci s různými nebo také žádnými zdravotními, sociálními a dalšími „problémy“). V tomto pojetí bychom v českých školách neměli nacházet rozdíly mezi pomyslnou normálností (normalitou) a jinakostí/jiností (odlišností). Svou jinakost/odlišnost tak může žák s CF vnímat $\mathrm{v}$ oblasti přístupu $\mathrm{k}$ němu, $\mathrm{v}$ obavách, které může vzbuzovat ve svém okolí, vnímaném strachu či pocitech nejistoty, zklamání a nenaplnění sociálních rolí. Hlavním nositelem těchto atributů ve formálním vzdělávání bývají 
především komunikace a postoje. Jinakost/odlišnost u žáků s CF je tak konceptualizována z perspektivy př́tomnosti nevyléčitelnosti a závažnosti onemocnění, které je smrtelné: (a) pohledem samotných nositelů, tj. žáky s CF; (b) pohledem rodičů, členů rodiny a nejbližších osob; (c) profesionálů (učitel, speciální pedagog, psycholog, poradce apod.). Jiný/odlišný je tak ve školní třídě právě žák s CF a ona jinakost je reflektována:

a) chronologickým (časovým) aspektem - limitovaný čas (pře)žití, funkční období bez rapidně progresivního zhoršení symptomatologie onemocnění, příp. období předtransplantační;

b) morálně-emočním aspektem - jde např. o (nemožnost) založení vlastní rodiny, problematiku odpovědnosti za své zdraví, ale také lítost ze strany okolí (pedagogického sboru i spolužáků), úlev daných zhoršujícím se zdravotním stavem, nemožnost rivality ve školním prostředí, velmi četné absence ve vyučování apod.

Jednotlivá témata, kterými může být jinakost/odlišnost žáků s CF založena a vnímána a která budou v textu dále popsána a interpretována, jsou:

1) symptomatologie onemocnění a vazba na jinakost/odlišnost a kvalitu života;

2) př́istup okolí (stigmatizace, viktimizace, socializace, postoje apod.);

3) prožívání, zkušenosti a uvědomění si blížící se konečnosti (strach ze smrti, úzkost, naděje, emoce, deprese, resilience, self-efficacy);

4) vyžadovaná podpora žáků (psychologická, psychosociální, sociální, emoční, svépomocné skupiny, vliv a působení rodičů, vztahové aspekty);

5) specifika výchovně-vzdělávacího procesu a komunikace.

\section{3 "Jinakost/odlišnost" daná symptomatologií a přítomností CF}

Pokrok v medicíně, stejně jako v dalších důležitých disciplínách podílejících se na zkvalitňování života, v posledních desetiletích dramaticky změnil průběh vrozených onemocnění a životní dráhy osob, které by dříve s vysokou pravděpodobností zemřely již $\mathrm{v}$ dětském věku. Vzhledem $\mathrm{k}$ lepší prognóze není již fenomén smrti a úmrtnosti jediným aspektem onemocnění, ale jde spíše o různá omezení daná přítomností CF. Žáci s CF čelí velkému množství 
omezení daných zejména terapeutickými intervencemi, které mnohdy zakládají otázku, kde je hranice mezi „normálností" a „jinakostí, odlišností“ (Kappler \& Griese, 2009). Péče o tuto skupinu dětských pacientů vyžaduje multidisciplinární přístup zahrnující širokou škálu odborností a v dětském věku je nezbytné rozpracovat také hledisko školní docházky a specifik výchovně-vzdělávacího procesu. CF (dříve také mukoviscidóza; ang. cystic fibrosis) je vrozené, chronické (celoživotní), progresivní a dědičně podmíněné smrtelné onemocnění. CF je současně vymezována jako onemocnění vzácné (rare disease). Přes značnou technizaci přístupu a moderní zlepšení terapeutického režimu je CF léčitelným, avšak ne vyléčitelným onemocněním. Hlavním symptomem je porucha funkce exokrinních žláz. Mezi příznaky patř́ vysoká koncentrace chloridů v potu a tvorba abnormálně vazkého hlenu v dýchacím, trávicím a pohlavním ústrojí (Fila, 2014). Velkým rizikem a také obavou nemocných je stav vedoucí až k respiračnímu selhání.

Symptomatologie CF je velmi široká. Náročnými stavy a komplikacemi bývají plicní exacerbace, pneumotorax, rozvoj broncho-pulmonálního onemocnění, hemoptýza, tzv. cepacia syndrom, plicní mykobakteriózy, př́tomnost nosních polypů, projevy insuficience zevní sekrece pankreatu, diabetes mellitus, gastroezofageální reflux, chronická metabolická alkalóza, neplodnost/ snížená plodnost a mnoho dalších specifických symptomů a syndromů, které se odvíjejí od formy, závažnosti a přítomnosti komplikací při základním onemocnění. Běžná symptomatologie CF zahrnuje produktivní kašel, opakované infekce plic a období častých hospitalizací a může způsobit negativní vnímání ostatními (Ernst, Johnson, \& Stark, 2010). Dopad na fyzické fungování, předčasná úmrtnost a sociální neakceptovatelnost symptomů mohou zapříčinit stigmatizaci dětí, žáků a dospívajících s CF. Další problémy lze spatřovat $\mathrm{v}$ emoční oblasti, $\mathrm{v}$ nízké sebeúctě, $\mathrm{v}$ pocitech bezmoci/bezmocnosti a v depresích (Berge \& Patterson, 2004). CF je život zkracující genetické onemocnění, které bývá spojováno se zhoršením psychosociálního fungování, stejně jako kvality života. Průměrná incidence tohoto onemocnění se uvádí 1 : 2500 (až 4500) novorozených dětí. U většiny dětí, kterým je diagnostikována CF, se současně objevuje také CHOPN (chronická obstrukční plicní nemoc), bronchiektázie (oblasti plic s abnormálně rozšířenými průduškami) a také pankreatická insuficience s následnou malnutricí. Kvůli pokroku v novorozeneckém screeningu, modernizaci a efektivitě komplexní terapie, stejně jako kontrole infektů u dětských pacientů, kterým byla diagnostikována CF v uplynulém desetiletí, se očekává, že přežijí do svých 50 let (Reid et al., 2011). Jen pro ilustrování pokroku a vývoje život prodlužujících intervencí 
lze uvést, že střední délka života byla v roce 1940 jeden rok, zatímco v roce 2006 to bylo 37 let (Grieve et al., 2011).

Léčba CF nicméně zahrnuje denní adherenci k intenzivnímu antibiotickému režimu, užívání vitamínových a enzymových preparátů, př́ijem vysoce kalorické stravy, používání inhalátoru a dechovou rehabilitaci s fyzioterapií hrudní oblasti. S tím souvisí zhoršené každodenní fungování, problémy v dodržování léčebného režimu, nízká sebeúcta a zhoršené psychosociální fungování. I přes značnou modernizaci komplexních přístupů a terapií stále zůstává značným problémem oblast způsobů, jakými se dětští pacienti vyrovnávají s příznaky onemocnění, prognostickou nejistotou a zátěží danou léčbou CF. Jak uvádějí Jamieson a kol. (2014) ve svém review kvalitativních studií, mezi šest identifikovaných témat, která zasahují do života a běžného fungování jedinců s CF, patří:

1) resilience (urychlení procesu získávání dospělých sociálních rolí, oblast převzetí odpovědnosti, akceptace prognózy, práce s kontrolou a sebekontrolou, sociální opora a oblast redefinování normality);

2) limitace životního stylu (omezení v nezávislosti, sociální izolace, pocit insuficience, fyzická neschopnost);

3) nepř́ijemnost a nelibost dlouhodobé léčby (oblast managementu vlastního zdraví, neúprosná a vyčerpávající terapie, nutnost respektovat režimová doporučení);

4) časová omezení (rizika, stanovení dosažitelných cílů, hodnota času);

5) emoční zranitelnost („nést břemeno“, oblast sebevědomí, finanční nejistota, ztráta jistoty);

6) očekávání transplantace a celková nejistota (potvrzení závažnosti onemocnění, následné nutnosti činit důležitá rozhodnutí, naděje a optimismu).

Žáci s CF disponují emoční zranitelností a současně schopností získat resilienci při zvládání jejich onemocnění. Oblast sebevědomí determinovaná projevy CF přispívá k jejich zranitelnosti (vulnerabilitě). Dlouhodobá zátěž vstupuje do životního stylu a vlastní nezávislosti, což se může projevovat ve specifické emoci - zášti. Děti s CF však rády posilují vlastní nezávislost a schopnost činit vlastní rozhodnutí. Co je pro tyto dětské pacienty typické, je 
efektivní využívání limitovaného času. Urychlení osobnostní zralosti a (z odpovědnosti bývají ve studiích často popisovanými fenomény. Častokrát se lze setkat s konstatováním, že děti s CF - ve srovnání se svými vrstevníky - sebe považují za zralejší a soucitnější osobnosti. S tím souvisí také fakt, že pokud zvládají náročnost života danou $\mathrm{CF}$, pak nebývají tolik zasaženy triviálními problémy, které řeší jejich vrstevníci a spolužáci. Pojem pushed into adulthood, který bývá spojován s životem CF, vymezuje to, že onemocnění „tlačí děti do dospělosti“ (Palmer \& Boisen, 2002). Přijmout prognózu vyžaduje akceptaci skutečnosti vlastního nevyléčitelného stavu, který zkracuje očekávanou (střední) délku života. Přesto se u osob s CF objevuje tendence žít př́ijemný život, jak jen to půjde, stejně jako snaha udržet co nejdéle pozitivní postoje (Moola \& Norman, 2011). Obnovení kontroly jde ruku v ruce s tím, že některé děti s CF pocitují ztrátu kontroly nad vlastním tělem, resp. fungováním těla. $V$ této oblasti je vhodné „ř́ídit své vlastní zdraví" a účastnit se běžných aktivit, jak jen to bude možné. Redefinování normality nastává u dětí s CF zpravidla tehdy, pokud se přestanou srovnávat se svými vrstevníky, ale budou v kontaktu s jinými dětmi s CF. Poté se zpravidla některé děti s CF učí respektu a akceptaci své vlastní aktuální fyzické schopnosti a učí se také vážit si aktuálního zdravotního stavu (D’Auria, Christian, \& Richardson, 1997). Děti a dospívající (především dívky) uvádějí závislost na rodičích v otázce podpory $\mathrm{v}$ dodržování pravidelnosti terapie. Paradoxně se lze setkat $\mathrm{s}$ informací, že ztráta rodičovské odpovědnosti v procesu osamostatňování se mladého dospívajícího přispěla k nástupu deprese. Zaostávat za ostatními znamená možnou sociální exkluzi kvưli častým absencím ve školních i mimoškolních aktivitách, a to pro časté exacerbace stavu a zhoršování funkční kapacity plic. Mohou se tak objevovat pocity vnímané nedostatečné podpory, důvěry v jejich vlastní schopnosti a v oblasti schopnosti podávat požadované dobré školní výkony (D’Auria et al., 2000).

Omezená nezávislost je determinována ztrátou svobody a př́ležitostí kvůli špatnému zdravotnímu stavu nemocných dětí a také značnou časovou náročností terapie a jejích každodenních intervencí. Některé děti s CF tak vnímají své rodiče jako „pletoucí se do všeho“, rozkazovačné nebo přespř́liš protektivní - samotné děti se cítí rozčíleně a jako nadmíru ochraňované, především neustálým připomínáním nutnosti užívání léků a dodržováním režimu ze strany rodičů. Na druhou stranu, mnoho dětí s CF vnímá tuto hyperprotektivitu ve vzájemné interakci jako zásadní a žádoucí - děti uvádějí, že by to „jinak vlastně nezvládly“ (aktivity, intervence, léky) (Barker et al., 2012). 
Jiné děti vnímají požadavek na vyšší míru vlastní odpovědnosti v průběhu dospívání (Hafetz \& Miller, 2010). Závislost na dostupné péči znamená, že starší děti volí kariérní možnosti (další studium, resp. přípravu na profesní roli) tak, že bývají omezeny na těsnou blízkost jejich domova nebo kliniky či zdravotnického zařízení, do kterého pravidelně docházejí. Fyzická nedostatečnost je dána př́tomností krátkozrakosti, slabosti, únavou a vyšším sklonem $\mathrm{k}$ infekcím. To vede $\mathrm{k}$ frustraci, sociální izolovanosti a pocitům jinakosti/odlišnosti. Navíc, zvýšená fyzická námaha si bere svou daň v podobě dopadu na zdraví a úbytku vnímané energie (Christian \& D’Auria, 1997). Děti s CF jsou tak konfrontovány s tím, že by si rády hrály, avšak nevolí tuto možnost z důvodu aktuálně pocitované únavy nebo únavy, kterou by samotná hra mohla vyvolat. Někteří chlapci s CF se mohou potýkat s tím, že by nemuseli mít ideální mužskou postavu. Děti s CF disponují několika vlastnostmi, které je „odlišují" od jiných dětí - většina z nich je menší než ostatní děti, hmotností lehčí a konstitučně drobnější. Pokud se u nich vyskytnou respirační problémy, úroveň jejich aktivity je značně omezená. Kvůli častému boji s infekcemi se stávají děti s CF snadno unavitelnými, ubývají na tělesné hmotnosti, ztrácejí sílu a celkově se necítí dobře. CF je onemocněním, před kterým nelze utéct - navíc ani není kam. Samotný fakt nevyléčitelnosti onemocnění dětem mnohdy připomíná neustálá potřeba užívat léky. Některé děti s CF tak nutnost léčby považují za jasnou indikaci toho, že jsou jiní/odlišní nebo slabší než jejich vrstevníci (spolužáci). Aspekt času je vymezen jistotou stinné budoucnosti (Moola \& Norman, 2011) a očekávanou kratší délkou života. $Z$ tohoto důvodu lze již v dětství pracovat s přesvědčením, že si děti (později dospělí jedinci) chtějí co nejvíce života užít, než aby se věnovali myšlenkám na zhoršující se budoucnost. Někdy se děti obávají toho, že zbytečně ztrácejí svůj čas, a jsou mnohdy také zoufalé ze zjištění, kolik času jim „sebrala“ nezbytná léčba. Proto je běžné, že i v dětství chtějí nemocní trávit co nejvíce času s rodinou, s přáteli a s nejbližšími (Willis, Miller, \& Wyn, 2001). $\mathrm{Z}$ hlediska školního výkonu i motivace $\mathrm{v}$ osobním nebo volném čase lze dohledat poznatek, že dospívající s CF chtějí více riskovat - odůvodňují to tím, že nemají ve svém již tak omezeném čase daném onemocněním co ztratit. Proto se můžeme setkat s tvrzeními založenými na faktu, že děti s CF - bez pocitu provinění - užívají drogy, konzumují alkohol, kouří a „kašlou na léčbu“ (Berge et al., 2007). Stejně tak mohou navštěvovat zakázaná místa s vyšším/ vysokým rizikem infekce (Russo, Donnelly, \& Reid, 2006). 
Být zátěží bývá interpretováno - skrze pocity dětí s CF - vysokou závislostí na rodinných př́íslušnících a každodenní odbornou péčí. Děti s CF se tak mohou dokonce cítit provinile za to, že odvracejí pozornost rodičů od svých sourozenců a omezují rodinu v čerpání dovolené. Citlivé děti s CF mohou tomuto faktu přisuzovat až zapříčinění problémů mezi jejich rodiči. $S$ tím souvisí vyšší finanční zátěž v rodině způsobená nákupem léků, které dítě s CF potřebuje, stejně jako finančními výdaji za vysoce kalorickou dietu. Mnoho dospívajících s CF vyjadřuje nespokojenost se sebou samými - ta je dána nižší tělesnou výškou, kašlem a nutností užívat léky také na veřejnosti. Pocity jinakosti/odlišnosti bývají navíc ještě podpořeny symptomy, které jim znemožňují zapojit se do společenských nebo pohybových (fyzicky náročnějších) aktivit. Některé děti tak maskují tuto odlišnost tzv. soukromým a společenským kašlem (private and social cough) nebo se vyhýbají užívání léků ve snaze vypadat normálněji. $\mathrm{V}$ těchto situacích jsou děti $\mathrm{s} C \mathrm{C}$ okolím označovány jako pacienti nebo postižení (Admi, 1996) a rozdílné zacházení s nimi ze strany učitelů, trenérů a pedagogů způsobuje frustraci a pocity ponížení. Právě proto je normální, že se některé děti s CF rozhodnou - dokud to jen půjde - neříct svým blízkým ani učitelům, že jsou vážně nemocní. Některé děti s CF se mohou začít cítit bezmocně v př́ípadě dalšího rozvoje onemocnění (Moola \& Norman, 2011). S tím souvisí také anticipované obavy - děti se bojí toho, že se u nich navíc objeví další onemocnění, především diabetes mellitus nebo deprese. Naděje a optimismus bývají často spojovány s transplantací - ta by jim měla zlepšit zdravotní stav, prodloužit očekávanou délku života a navýšit šanci být normální jako ostatní (Christian, D’Auria, \& Moore, 1999). Zdá se, že pocit, že se děti s CF odlišují od ostatních, je znatelnější u mladších dětí. Některé starší děti a adolescenti mohou ve vlastním onemocnění spatřovat příčinu dřívějšího dosažení dospělosti. To je motivuje přijmout jejich nemoc a dodržovat režim nezbytně nutný pro léčbu onemocnění, a co nejvíce a nejčastěji tak žít běžný - můžeme říci „normální" - život jako ostatní. Stádium onemocnění a symptomatologie tak hraje prim v oblasti kontroly onemocnění a účasti na sociálních, školních a pohybových aktivitách. Je však samozřejmé, že děti s nejnáročnější fází CF zažívají pocity bezmoci (Jamieson et al., 2014).

Pocit odlišnosti bývá i v rámci homogenní skupiny dětí s CF pozorován mezi chlapci a dívkami. Dospívající dívky s CF často zdůrazňují emocionální zátěž, větší bolest a trávení více času v nemocnici než chlapci v podobných stadiích CF (Groeneveld et al., 2012) a disponují horší prognózou než chlapci (Nick et al., 2010). Chlapci častěji přebírají zodpovědnost za svou léčbu a zastávají 
pozitivnější postoje než dívky, které disponují vyšší potřebou sdílet odpovědnost (nejčastěji s rodiči nebo s lékaři). Přestože by některé děti rády sdílely svá trápení, radosti a úspěchy se stejně nemocnými face-to-face, není to možné z důvodu hrozící infekce. Někteří chlapci také vyjádřují obavu o vlastní zdraví, a tak bývají motivovanější k pravidelnému cvičení vedoucímu ke zvýšení svalové hmoty. Děti a dospívající s CF popisují prožitek ztráty normality stejně jako lidé žijící s jiným chronickým a život ohrožujícím onemocněním - jmenujme kupř́kladu rakovinu, juvenilní idiopatickou artritidu, chronická onemocnění ledvin apod. (Tong et al., 2012). S poklesem plicních funkcí a s nárůstem symptomatologie (upozorňující na zhoršování stavu) souvisí vyjadřovaná úzkost, izolace a nejistota. Spolužáci, kteří nebyli dostatečně, nebo dokonce vůbec, edukováni o základních aspektech $\mathrm{CF}$, tak mohou dokonce opustit děti a dospívající s CF z důvodu mylné domněnky, že by se mohli kašlem dětí $s \mathrm{CF}$ sami nakazit. $\mathrm{V}$ současné době se jako vhodné jeví naplňovat dlouhodobé potřeby dětí a dospívajících s CF, kteří budou žít déle, přičemž dominantní místo $\mathrm{v}$ hierarchii potřeb mají potřeby psychosociální. Je všeobecně známo, že dlouhodobé nebo celoživotní onemocnění zapříčiňuje dysfunkčnost potřeb - ta následně zasahuje nejen samotné dítě, ale i fungování rodiny jako celku (Sochocka, Noczyńska, \& Wojtyłko, 2011). Rovněž se posuzuje psychosociální fungování a rizikové chování související se zdravím u dospívajících (Hagel et al., 2009), s čímž také souvisí další anticipovaná obava a smutek: vnímání vlastní sexuality, obavy spojené se sexuálním fungováním a neplodnost.

\section{Jinakost/odlišnost založená stigmatizací}

Výzkumy, které se zaměřují na studium stigmatu u osob s CF, jsou četnostně značně omezené. Produktivní kašel, opakované plicní infekce a období, která vyžadují hospitalizaci, patř́i mezi běžné př́iznaky CF. Tyto př́iznaky však mohou způsobit negativní vnímání ostatními. V zahraničí byla sestavena škála Stigma Scale, která je specificky určená osobám s CF (CF-specific Stigma Scale). S pomocí tohoto instrumentu lze fenomén stigmatu považovat za měřitelný. Škála zakládá východiska na konstatování, že právě stigma u dětí (osob) s CF významně ovlivňuje život (a jeho kvalitu) (Pakhale et al., 2014).

Stigma související se zdravím (health-related stigma) je definováno jako osobní zkušenost se specifickými charakteristikami v podobě vyloučení, odmítnutí, viny nebo podceňování vyplývajícími z daných očekávání a negativních 
soudů osob v blízkém okolí nemocné osoby (Cataldo et al., 2011). Podobně na stigma související se zdravím nahlížejí Lebelová a Devins (2008): jde o sociální proces, při kterém zkušenost nebo očekávání negativního společenského úsudku založeného na zdravotním stavu jedince/skupiny vedou k sociálnímu odmítnutí, pocitům viny či devalvaci vlastní osobnosti.

Stigma bývá spatřováno také ve formě očekávaného stigmatu - děti a dospívající s CF disponují zkušenostmi, že se v důsledku chronického onemocnění léčí jinak než ostatní. Stigma je spojeno se sociálním stresem a s negativními dopady na psychické a fyzické zdraví nemocných. Tento názor je založen na Goffmanově (1963) klasické ideologii stigmatu, která rozlišovala mezi přijatým/přijímaným stigmatem (tj. zkušenostmi s diskriminací, ke které došlo) a vnímaným stigmatem (tj. obavou z izolovanosti nebo odmítnutí jinými). Goffman odlišuje discredited osoby, jejichž stigmatizovaná charakteristika je zřejmá nebo ostatním známá (např. obezita, fyzické deformity), a discreditable osoby, jejichž stigmatizovaná charakteristika může být skrytá (např. AIDS, duševní onemocnění). Bylo prokázáno, že stigma má významný dopad na celkový zdravotní stav a kvalitu života a u dětí s CF může být toto stigma spojováno s nižším (nedostatečným) dodržováním jejich léčebného režimu. U osob s CF bývá stigmatizace spojována s poklesem sociálních kontaktů, se zhoršujícími se vztahy a s poklesem morálky, které mohou vést ke zhoršení funkce plic, poklesu tělesné hmotnosti a ke změnám ve fyzickém fungování (Pizzignacco, de Mello, \& de Lima, 2010). Komplexní průběžná péče, celoživotní příznaky a dědičná povaha onemocnění činí osoby s CF zranitelnými vůči působení stigmatu souvisejícího s jejich onemocněním. Stigma spojené s chronickými onemocněními souvisí s horším fyzickým a psychickým zdravím, avšak ukazuje se, že protektivně působí optimismus.

Vztah mezi stigmatem a optimismem zkoumala např́íklad studie Oliverové a kol. (2014). Zjistili, že vyšší míra stigmatizace je spojena s poklesem (zhoršením) plicních funkcí a kvalitou života. Stigma u nemocných s CF souvisí také s psychickým zdravím - vyšší míra optimismu může působit jako ochranný faktor. Navíc, styl copingu charakterizovaný optimistickou akceptací onemocnění bývá spojován s lepší kvalitou života - zejména s jejími psychosociálními doménami. Optimismus a rozptylování (distraction) byly silně spojeny s emocionálními reakcemi, společenským fungováním a mezilidskými vztahy. Vysoká míra optimismu byla spojena s lepšími hodnotami kvality života související se zdravím (HRQoL) a vysoká míra rozptylování s horšími 
(nižšími) hodnotami HRQoL. U některých domén měly optimismus a rozptýlení vyvážený efekt, takže rozdíl mezi nimi může být důležitým prediktorem HRQoL (Abbott et al., 2008).

$\mathrm{V}$ jisté paralele lze sledovat i vztah optimismu směrem $\mathrm{k}$ podpoře samostatnosti dětí a menší až žádné závislosti na rodičích, což souvisí s konceptem self-efficacy, který podporuje self-management vlastního onemocnění (McDonald, Haberman, \& Brown, 2013). U dospívajících s CF může vyšší úroveň self-efficacy facilitovat překonávání bariér ve vzdělávací dráze, stejně jako dopadů absencí ve školní docházce, požadavků na terapii a rozdílností v tělesném vzhledu. Situace, které směřují ke stigmatizaci, zahrnují fyzické deformity, projevy onemocnění a případně také př́íslušnost $\mathrm{k}$ „jiné“ sociální skupině či etniku včetně náboženství. Zvláště v období dospívání může být stigma obzvláště důležitou formou psychosociálního stresu (identita, nezávislost na rodičích, sociální fungování a samostatnost). S tím úzce souvisí také popisovaná sociální úzkost (změna prostředí, změna vztahů, skrývání diagnózy, bagatelizace projevů na veřejnosti, záměrné vynechání léků apod.) (Pizzignacco et al., 2010). Napříč věkovými skupinami pacientů s CF lze konstatovat, že tito trpí nejen stigmatem daným přítomností onemocnění, ale také zkrácením délky života a vysokou zátěží v podobě každodenní léčby, což může být ještě více stigmatizující (Goffman, 1963). Sociální stigma může být spojeno s psychickým distresem, který by mohl následně ovlivnit kvalitu života související se zdravím (tj. již výše zmíněný koncept HRQoL).

\section{Jinakost/odlišnost daná strachem ze smrti a strachem z budoucnosti}

Děti s CF častokrát zažívají bolest (invazivní procedury) již v raném dětství. Mnohdy je různá vyšetření a intervence děsí. Používání vhodných strategií $\mathrm{k}$ redukci či minimalizaci bolesti a strachu může posílit compliance (ochotu spolupracovat a dodržovat režimová či terapeutická opatření) těchto dětí/ žáků později v dospívání a v dospělosti. To vše velmi úzce souvisí také se strachem ze smrti (fear of death) a strachem z progrese onemocnění (fear of disease progression). Dotýkají se jak samotných nemocných dětí, tak jejich rodičů a blízkých. Jde o významné zdroje stresu, které bývají doplněny o strach $\mathrm{z}$ budoucnosti (fear of the future). Výše uvedené typy strachu jsou studovány $\mathrm{v}$ průběhu času pro svou souvislost s úzkostí, depresí a negativním dopadem na kvalitu života (Koch et al., 2013). Strach z progrese onemocnění bývá 
přítomen také u rodičů dětí s různými chronickými stavy, zejména pokud je onemocnění život ohrožující a progresivní povahy; takovými onemocněními jsou - kromě CF - roztroušená skleróza v dětství nebo mukopolysacharidóza (Fidika et al., 2015). Rodiče dítěte s CF se musí vyrovnat s trvalou hrozbou, že i přes dostupnou léčbu se onemocnění jejich dítěte nevyhnutelně rozvíjí i nadále. Rodiče mohou vnímat zprostředkovaný strach, včetně strachu z bolesti, jako by oni sami byli nemocnými. Boylová a kol. (1976) zmiňují čtyři specifické zdroje stresu, které mohou způsobit emocionální zátěž a problémy u dětí a žáků s CF: (1) změněný fyzický vzhled, (2) napjaté mezilidské vztahy, (3) rostoucí obavy z budoucnosti a (4) konflikty v rodičovských postojích a ve výchově.

Se strachem ze smrti nebo z budoucnosti souvisí taktéž problematika úzkostí a př́ípadných depresí. Ty se týkají jak samotných dětí a dospívajících, tak jejich rodičů. Ti se musejí vyrovnávat s nejistotou ohledně progrese stavu jejich dítěte, stejně jako s problémy v každodenním fungování rodiny a podpory, včetně nutnosti respektování složitých a náročných terapeutických režimů, návštěv v nemocnicích a narušení plánování do budoucna. Studie Besierové a kol. (2011) přináší zjištění, že více než třetina $(37,2 \%)$ rodičủ zapojených ve studii ( $\mathrm{N}=650$ rodičů pečujících o 564 dětí) vykazovala zvýšenou úroveň symptomů úzkosti a také deprese. Obojí pak úzce korelovalo s poklesem úrovně životní spokojenosti, respektive (v dalších studiích) s poklesem celkové kvality života. Rodiče zažívají pocity viny, odmítání, popírání a strachu v reakci na CF jejich dítěte (Tluczek et al., 2015). Obavy spojené s depresí, mnohdy „doplněné“ problémy s koncentrací, nedostatkem motivace, zpomalením psychomotorického tempa a zhoršeného sociálně-vztahového fungování, negativně ovlivňují školní výkon dítěte/žáka. Závažnost onemocnění (stavu), styl copingu a podpora rodiny byly identifikovány jako faktory minimalizující vznik či rozvoj psychiatrických poruch u dětí/žáků s CF (Pfeffer, Pfeffer, \& Hodson, 2003).

\section{Jinakost/odlišnost založená specifiky výchovně-vzdělávacího procesu}

Jak již bylo naznačeno výše, problematické aspekty, které mohou být součástí jinakosti/odlišnosti žáků s CF, se vyskytují také v edukačním procesu. Daná skutečnost se bezprostředně týká všech oblastí edukace jedince, tedy oblastí preprimárního, primárního i sekundárního vzdělávání. Problematické 
aspekty spojené s CF se netýkají pouze samotných nositelů daného onemocnění (tedy již zmíněných žáků s $\mathrm{CF}$ ), ale i jejich rodičů, spolužáků a učitelů, kteří představují v oblasti edukace klíčový segment. Přístup učitele $\mathrm{v}$ rámci procesu edukace žáků $\mathrm{s} C \mathrm{C}$ by měl bezpodmínečně korelovat $\mathrm{s}$ individuálními (vzdělávacími) potřebami a specifiky jednotlivých žáků. Důležitým prvkem při vlastním plánování edukačních aktivit a plnění povinné školní docházky žáka s CF je taktéž seznámení pedagoga se skutečností, že tito žáci jsou konstitučně slabší než jejich intaktní spolužáci, mívají hubenější končetiny nebo zvětšené břicho.

Pro zvyšování kvality procesu edukace se jeví jako vhodná modifikace školního prostředí (oblast materiální, architektonická, interpersonální, vztahově-sociální apod.). Aktivní př́istup učitele, ale také jeho lidský i profesní zájem o problematiku CF a její specifika vede $\mathrm{k}$ vytváření takového školního prostředí, které umožňuje žákovi s CF prožívat v edukačním procesu úspěch, a tím také stírá jinakost/odlišnost. Zkušenost $\mathrm{s}$ úspěchem při překonávání překážek ovlivňuje př́ípadné zvyšování míry pocitu sebevědomí a sebeúcty žáka s CF (Grieve et al., 2011). Úprava školního prostředí je v př́ípadě edukace žáků $\mathrm{s} C F \mathrm{z}$ důvodu rizik plynoucích z jejich onemocnění opravdu velmi důležitá.

Učitel minimalizuje rizika směřující k rozvoji infekčního (i neinfekčního) onemocnění žáka s CF a měl by za tímto účelem konat nezbytná strategická a efektivní preventivní opatření. S tímto úzce souvisí například podpora pohybových aktivit, dechová rehabilitace či hygiena odkašlávání. Žák s CF by měl mít možnost žít natolik normální a neomezený život, nakolik mu to jen jeho aktuální zdravotní stav dovolí (Chrastina et al., 2015). 0 zapojení žáka s CF do výchovně-vzdělávacího procesu v běžných školách hovoří také Carson (2015); Cystic Fibrosis Trust (2016); Cystic Fibrosis Canada (2014); Hanxhiu a kol. (2017); Mighten a Overend (2016) a další. Jinakost/odlišnost může být založena četnými absencemi žáků s CF, které jsou dány specifiky léčby, pravidelností a každodenností režimu (ranní hygiena dýchacích cest, dechová rehabilitace apod.), zhoršením zdravotního stavu žáka nebo jeho př́ípadnými hospitalizacemi (Chrastina et al., 2015).

Dále je nutné u žáků s CF pracovat s požadavkem užívání léků (enzymů, antibiotik, mukolytik, expektorancií, broncho-dilatancií, kortikoidů apod.), a to $\mathrm{v}$ pravidelných intervalech. Některé léky totiž mohou ovlivňovat i pozornost a projevy chování žáka. S rizikem přenosu infekčních onemocnění 
souvisí i jedna z dalších povinností učitele, a to konkrétně povinnost maximální eliminace míst, na kterých by mohlo docházet k reprodukci (pro žáky s CF) velmi nebezpečné bakterie Pseudomonas aeruginosa. Někteři žáci s CF mohou v určité fázi onemocnění potřebovat pro aplikaci léků dlouhodobý intravenózní vstup nebo nazogastrickou sondu a perkutánní endoskopickou gastrostomii (PEG), které činí žáky s CF „jinými“, staví je do role pacienta. Pokud nebude učitel věnovat ve třídním kolektivu dostatečný prostor komunikaci s žáky týkající se daného tématu, může ve třídním kolektivu dojít ke zrodu ostrakismu a následné šikany. Zkušenosti s rizikem šikanování se stále častěji vyskytují i u dětí se speciálními vzdělávacími potřebami.

Ostrakismus a viktimizace ohrožují potřeby dítěte v podobě sebevědomí, pocitu sounáležitosti, smyslu pro kontrolu a smysluplnou existenci. Studie Twymanové a kol. (2010) se, kromě cílové skupiny dětí s CF, zaměřila na srovnání výše uvedených atributů u skupin dětí s poruchami učení, s poruchami autistického spektra a S ADHD, a využila nástroje the Bully-Victimization. Pozitivním zjištěním bylo, že skupina dětí s CF sebe samé neuvedla jako oběti šikanování či viktimizace.

\section{Jinakost/odlišnost v oblasti psychosociální podpory}

Jedinci s CF označují své onemocnění jako situaci nepředvídatelnou, progresivní a život limitující (Higham, Ahmed, \& Ahmed, 2013). Vzhledem k multisymptomatologické povaze a aspektu progrese onemocnění nabývá na důležitosti psychosociální podpora. Bývá vyžadována podpora, která jedincủm s CF umožňuje vyrovnat se především s nejistotou doprovázející onemocnění, tedy nejen s jeho medicínskými aspekty (Badlan, 2006). Gjengedalová a kol. (2003) uvádějí, že většina účastníků výzkumu byla již od svého raného dětství obeznámena s aspektem terminálnosti onemocnění, nicméně až s postupem času pochopili jeho skutečný dosah a závažnost.

CF je onemocněním vyžadujícím časově náročnou každodenní léčbu, která představuje zátěž nejen pro samotné žáky, ale také pro osoby o ně pečující (Fidika et al., 2015). Je důležité uvědomit si, že rovněž učitelé se mohou ve své každodenní praxi setkat s ojedinělými př́pady žáků s tímto onemocněním, a měli by tedy být připraveni poskytnout požadovanou podporu. Tato úloha může být ztížena situací, kdy má učitel k dispozici pouze malé množství informací o komplexních a složitých tématech spjatých s problematikou onemocnění (Bradley-Klug et al., 2010). Za významnou determinantu úspěšnosti 
tohoto „úkolu“ lze z obecného hlediska považovat také postoj školy a zázemí, které vytváří nejen svým žákům, ale také zaměstnancům. Např́íc odbornými zahraničními zdroji je možné nalézt informace o multidisciplinárním přístupu aplikovaném v prostředí vzdělávacích institucí. Učitelé disponující aktuálními informacemi o zdravotním stavu žáka mohou poté flexibilně reagovat také na měnící se psychosociální potřeby žáků a modifikovat svůj přístup. Potřebu spolupráce mezi zdravotnickým personálem a učiteli při naplňování potřeb žáků zdůrazňují také Bradley-Klug a kolegové (2010). Ti mimo jiné poukazují na důležitost role školního psychologa, jenž by podle autorů měl být prostředníkem mezi školou a zdravotnickým personálem a jeho klíčová úloha spočívá v iniciaci změn s důrazem na oblast prevence a intervence v rámci psychosociální podpory žákủ (tamtéž). Klíčovým faktorem při budování funkční spolupráce multidisciplinárního týmu je důvěra.

K dosažení optimálního stavu žáka je nezbytné, aby všichni zúčastnění (žák, rodiče, zdravotnický personál, zaměstnanci školy) pracovali na vztahu založeném na důvěře. Vztahy mohou být lehce narušitelné kupř. neefektivní komunikací, proto lze budování vztahů v rámci multidisciplinárního týmu označit za nikdy nekončící práci (Strawhacker \& Wellendorf, 2004). Jak je uvedeno výše, nedílnou součástí týmu jsou rodiče žáka. Rodiče se cítí být izolováni od okolního světa (Gormley et al., 2014), často se u nich objevuje úzkost spojená především se strachem z progrese onemocnění. Dalším „zátěžovým“ prvkem je sdílení zodpovědnosti při léčbě dítěte (Fidika et al., 2015). Péče o dítě s CF staví rodiče před mnohá dilemata. Rodiče vědí, nakolik je pro jejich dítě důležitá fyzická aktivita, snaží se dítě motivovat a povzbuzovat $\mathrm{k}$ účasti na běžných hrách se svými vrstevníky. Nicméně je nezbytné dodržovat léčebný režim a stává se, že $\mathrm{v}$ důsledku toho, aby se dítě necítilo být odlišné (tím, že opustí hřiště dříve), rodiče daný režim obměňují (Gjengedal et al., 2003). Informovanost rodičů lze považovat za stěžejní aspekt úspěšné psychosociální podpory. $V$ konsenzu s tímto by rodiče ocenili vznik podpůrných svépomocných skupin (Gormley et al., 2014). V rámci psychosociální podpory je zapotřebí věnovat zvýšenou pozornost výše zmíněné problematice „přechodových“ fází v životě člověka. $Z$ toho důvodu se jeví jako vhodné aplikovat také možnou psychoterapeutickou intervenci u nemocných s CF a jejich blízkých osob. Přestože psychoterapie nespadá přímo do pedagogické praxe, školní psycholožky a psychologové mohou být první linií při nabízení této možnosti podpory - současně je tak možné efektivně pracovat s rodiči nemocných dětí/žáků, případně dalšími členy rodiny, stejně jako 
členy pedagogického sboru. Možné intervence v podobě review nabízí např́íklad Glasscoe a Quittner (2003), kteří uvádějí vhodnost biofeedbacku, masáží, muzikoterapie při fyzioterapii, kognitivně-behaviorální terapie v oblasti zlepšení (problematického) stravování a další intervence reagující na specifické obavy dětí/žáků z léčby během vysoce zátěžových etap v průběhu onemocnění. Jako vhodné doporučení autoři uvádějí podporu a psychoterapii také osobám pečujícím, které jsou v každodenním kontaktu s dětmi/žáky. Patřičnou pozornost zasluhují také rodiče nemocných dětí/žáků, kteří mohou disponovat zátěží plynoucí z role nejbližších pečujících (Goldbeck et al., 2014), případně trpět depresí a úzkostí (Quittner et al., 2014).

Úspěšné zvládání onemocnění v období jistého sociálního přechodu, což může být kupříkladu nástup puberty u žáků, vyžaduje značnou flexibilitu a podporu rodiny a přátel (Barker et al., 2012). Je zřejmé, že nastalá situace bude vyžadovat také specifický přístup učitele. Při práci s dospívajícími žáky s CF se problematika léčby onemocnění odvíjí na pozadí rapidních fyzických, psychických a sociálních vývojových změn. $\mathrm{V}$ žádném jiném životním období nedochází k tak úzkému spojení biologických a psychosociálních prvků onemocnění a chování jako v adolescenci (Segal, 2008). Pro představu a uvědomění si složitosti problematiky se jeví jako vhodné uvedení změn, které se v průběhu psychického a sociálního vývoje dospívajících žáků objevují. V oblasti psychického vývoje se jedná o změnu myšlení od konkrétního k abstraktnímu, patrné je vnímání sebe sama jako „nedotknutelné“ osoby, rozvíjí se sexuální identita, mění se vnímání vlastního těla, vzrůstá schopnost vzdělávání se - do popředí se dostává rozhodování o budoucí profesi, žáci začínají vnímat nuance $\mathrm{v}$ oblasti morálky. Dochází $\mathrm{k}$ identifikaci s vrstevníky, objevuje se zájem o druhé pohlaví (LGBT+) a s tímto spojené vyjadřování sexuality - žáci experimentují s kouřením a dalšími formami rizikového chování (Segal, 2008). Změny, které v psychosociálním vývoji žáka probíhají, lze označit za markantní, v případě žáků s CF dochází k vzájemnému ovlivňování těchto změn s onemocněním. CF se stává automatickou součástí dospívajícího žáka. $V$ důsledku působení CF na psychický vývoj žáků dochází $\mathrm{k}$ jisté formě infantilního chování žáků. V mnoha případech se žáci adaptují na tzv. roli nemocného, jejich chování lze označit za egocentrické. Narušené je rovněž vnímání vlastní sexuální atraktivity v důsledku slabé tělesné konstituce, což je spjato s povahou onemocnění. V neposlední řadě se u žáků s CF mohou objevit sklony k depresím (tamtéž). 
Akceptaci onemocnění lze označit za složitý proces mající vliv na emoce jedince. Akceptace onemocnění poté působí na subjektivní vnímání vlastní osoby jedincem trpícím daným onemocněním. I v případě přijetí onemocnění na kognitivní úrovni se prožívání může vyznačovat přítomností negativních emocí, které významně ovlivňují život jedince, jak tvrdí Badlanová (2006). Táž autorka považuje za důležité, aby si odborníci z oblasti zdravotnictví uvědomovali možnost pocitu izolace u svých pacientů a snažili se danou skutečnost reflektovat a odhadnout, jakým způsobem bude ovlivňovat chování mladých lidí s CF ve vztahu k léčbě. Jak podotýká Segal (2008), vzhledem ke zmíněným komplikacím onemocnění se dospívajícím žákům nedaří navazovat partnerské vztahy. Dospívající je zapojen do procesu rozhodování o léčbě a dalších intervencích (tamtéž). Možnost být zapojen do tohoto procesu hodnotí jedinci s CF jako podstatnou determinantu poskytované podpory (Badlan, 2006). Velmi důležité je zajištění kontinuity péče. Svou roli sehrávají podpůrné skupiny, o jejichž existenci je dospívající žák informován, nicméně záleží pouze na jeho volbě, zda se stane členem skupiny, či nikoliv. Existuje reálná možnost, že se žák bude těmto skupinám vyhýbat ve snaze začlenit se do „normálního“ kolektivu (Segal, 2008).

\section{Závěr}

V textu byla tematizována jinakost/odlišnost dětí, žáků a studentů, která je založena přítomností CF. Na koncept jinakosti/odlišnosti bylo nahlíženo pohledem limitací, se kterými je jedinec každodenně konfrontován - jde o specifika vyplývající z onemocnění. Zmíněná jinakost/odlišnost se dotýká mnoha oblastí života jedince. Oblast komplexního přístupu a podpory osob $\mathrm{s} C F$ je značně rozsáhlá. $\mathrm{Z}$ tohoto důvodu byla autory cíleně zvolena témata, o kterých se domnívají, že by mohla zakládat jinakost/odlišnost dětí, žáků a studentů s CF. Na základě rešeršní činnosti byla identifikována a následně deskribována témata symptomatologie onemocnění, vazby na jinakost/ odlišnost a kvalitu života. Dále byl deskribován přístup okolí k nositeli onemocnění, a proto je řešena rovněž problematika stigmatizace, viktimizace, socializace a postojů společnosti. Neméně důležitým aspektem majícím vliv na vnímání jinakosti/odlišnosti je prožívání přítomnosti CF nejen samotným nositelem onemocnění, ale i jeho blízkým okolím. Zkušenosti související s přítomností $\mathrm{CF}$, stejně tak jako uvědomění si konečnosti vybraného infaustního onemocnění, jsou neodmyslitelnou doménou řešené oblasti problematiky. S percepcí přítomnosti $\mathrm{CF}$ u dětí, žáků a studentů v podobě 
závažného, nevyléčitelného a smrtelného onemocnění úzce souvisí také nutnost specifické podpory (psychické, psychosociální, sociální, emoční apod.). Problematické aspekty vyplývající z onemocnění, které mohou být součástí jinakosti/odlišnosti, se vyskytují ve výchovně-vzdělávacím procesu, jeho nezbytných modifikacích či individuálně koncipovaných přístupech učitele jako klíčové osoby participující na inkluzivním vzdělávání.

Další výzkumné aktivity by měly, podle autorů příspěvku, být zaměřeny na přípravu budoucích i stávajících učitelů v problematice umírání žáka, v procesech vyrovnávání se s psychosociální zátěží; dále by měly (pro naše sociokulturní prostředí) rozpracovat měřitelnost stigmatu, kvality života (v podobě specifického instrumentu), stejně jako self-efficacy a strategií copingu. Jako výzvu autoři příspěvku považují rozpracování témat každodenní percepce subjektivního stavu daného aktuální zdravotní situací dítěte/žáka a př́ípadných přání (požadavků) dětí s CF, respektive konceptualizování pojmu potreby dětí $s C F$ pro následnou aplikaci do edukačního procesu a jeho teorií. Jako velice významná témata se rovněž jeví práce s nadějí, specifika časového období end-of-life, s tím související paliativní nebo hospicová péče věnovaná žákovi s CF a rovněž problematika "normálnosti života" v podobě aktivit směřujících k podpoře žáka a k práci s konceptem blížícího se úmrtí spolužáka ve třídním kolektivu. Jinakost/odlišnost žáka popisovaná ve spojení s CF spočívá v jeho specifických potřebách, které vyplývají z případných změn zdravotního stavu a postojů jeho okolí. Současný stav vzdělávání v našich podmínkách, které respektuje požadavek společného vzdělávání, by měl př́padné jinakosti/odlišnosti a rozdílnosti stírat.

\section{Literatura}

Abbott, J., Hart, A., Morton, A., Gee, L., \& Conway, S. (2008). Health-related quality of life in adults with cystic fibrosis: The role of coping. Journal of Psychosomatic Research, 64(2), 149-157.

Adamus, P. (2015). Metodika hodnocení kvality inkluzivní školy. Opava: Slezská univerzita v Opavě.

Admi, H. (1996). Growing up with a chronic health condition: A model of an ordinary lifestyle. Qualitative Health Research, 6(2), 163-183.

Badlan, K. (2006). Young people living with cystic fibrosis: An insight into their subjective experience. Health \& Social Care in the Community, 14(3), 264-270.

Barker, D. H., Driscoll, K. A., Modi, A. C., Light, M. J., \& Quittner, A. L. (2012). Supporting cystic fibrosis disease management during adolescence: The role of family and friends. Child: Care, Health and Development, 38(4), 497-504. 
Besier, T., Born, A., Henrich, G., Hinz, A., Quittner, A. L., \& Goldbeck, L. (2011). Anxiety, depression, and life satisfaction in parents caring for children with cystic fibrosis. Pediatric Pulmonology, 46(7), 672-682.

Berge, J. M., \& Patterson, J. M. (2004). Cystic fibrosis and the family: A review and critique of the literature. Families, Systems \& Health, 22(1), 74-100.

Berge, J. M., Patterson, J. M., Goetz, D., \& Milla, C. (2007). Gender differences in young adults' perceptions of living with cystic fibrosis during the transition to adulthood: A qualitative investigation. Families, Systems \& Health, 25(2), 190-203.

Boyle, I. R., di Sant'Agnese, P. A., Sack, S., Millican, F., \& Kulzycki, L. L. (1976). Emotional adjustment of adolescents and young adults with cystic fibrosis. Journal of Pediatrics, 88(2), 318-326.

Bradley-Klug, K. L., Sundman, A. N., Nadeau, J., Cunningham, J., \& Ogg, J. (2010). Communication and collaboration with schools: Pediatricians' perspectives. Journal of Applied School Psychology, 26(4), 263-281.

Cannadine, D. (2013). The undivided past: Humanity beyond our differences. New York: Alfred A. Knopf.

Carson, M. A. (2015). Identifying health, educational, and social emotional needs and potential intervention strategies for children with cystic fibrosis first entering elementary school (Disertační práce). Dostupné z https://search.proquest.com/docview/1722047962?pqorigsite $=$ gscholar

Cataldo, J. K., Slaughter, R., Jahan, T. M., Pongqun, V. L., \& Hwang, W. J. (2011). Measuring stigma in people with lung cancer: Psychometric testing of the Cataldo lung cancer stigma scale. Oncology Nursing Forum, 38(1), 46-54.

Cystic Fibrosis Canada. (2014). Education and cystic fibrosis. Dostupné z http://www. cysticfibrosis.ca/uploads/resources/overall/EN_EDUCATION_AND_CF_WEB_Compressed. pdf

Cystic Fibrosis Trust. (2016). School and cystic fibrosis: A guide for parents from pre-school to primary. Dostupné z https://www.cysticfibrosis.org.uk/ /media/documents/life-withcf/education-and-employment/schools-pack-2016.ashx

D’Auria, J. P., Christian, B. J., \& Richardson, L. F. (1997). Through the looking glass: Children's perceptions of growing up with cystic fibrosis. The Canadian Journal of Nursing Research, 29(4), 99-112.

D’Auria, J. P., Christian, B. J., Henderson, Z. G., \& Haynes, B. (2000). The company they keep: The influence of peer relationships on adjustment to cystic fibrosis during adolescence. Journal of Pediatric Nursing, 15(3), 175-182.

Dogan, S. (2000). Turkey, as "other" and being "othered" (Závěrečná práce). Dostupné z http:// selcengur.com/TurkeyAsOther.pdf

Ernst, M. M., Johnson, M. C., \& Stark, L. J. (2010). Developmental and psychosocial issues in cystic fibrosis. Pediatric Clinics of North America, 58(4), 865-885.

Fidika, A., Herle, M., Herschbach, P., \& Goldbeck, L. (2015). Fear of disease progression questionnaire for parents: Psychometric properties based on a sample of caregivers of children and adolescents with cystic fibrosis. Journal of Psychosomatic Research, 79(1), 49-54.

Fila, L. (2014). Cystická fibróza u dospělých. Interní medicína, 16(2), 54-60. 
Gallos, J. V., \& Ramsey, V. J. (1997). Teaching diversity: Listening to the soul, speaking from the heart. San Francisco: Jossey-Bass Publishers.

Gjengedal, E., Hanestad, B. R., Rustøen, T., \& Wahl, A. K. (2003). Growing up and living with cystic fibrosis: Everyday life and encounters with health care and social services - a qualitative study. Advances in Nursing Science, 26(2), 149-159.

Glasscoe, C. A., \& Quittner, A. L. (2003). Psychological interventions for cystic fibrosis. The Cochrane database of systematic reviews. Dostupné z http://cochranelibrary-wiley.com/ doi/10.1002/14651858.CD003148/abstract

Goffman, E. (1963). Stigma: Notes on the management of a spoiled identity. Harmondsworth: Penguin.

Goldbeck, L., Fidika, A., Herle, M., \& Quittner, A. L. (2014). Psychological interventions for individuals with cystic fibrosis and their families. The Cochrane database of systematic reviews. Dostupné $\mathrm{z}$ http://cochranelibrary-wiley.com/doi/10.1002/14651858. CD003148.pub3/abstract

Gormley, H., Duff, A., Brownlee, K., \& Hearnshaw, C. (2014). What parents of children with cystic fibrosis expect of educational events. Nursing Children \& Young People, 26(7), 21-24.

Grieve, A. J., Tluczek, A., Racine-Gilles, C. N., Laxova, A., Albers, C. A., \& Farrell, P. M. (2011). Associations between academic achievement and psychosocial variables in adolescents with cystic fibrosis. The Journal of School Health, 81(11), 713-720.

Groeneveld, I. F., Sosa, E. S., Pérez, M., Fiuza-Luces, C., Gonzalez-Saiz, L., Gallardo, C., LópezMojares, L. M., Ruiz, J. R., \& Lucia, A. (2012). Health-related quality of life of Spanish children with cystic fibrosis. Quality of Life Research, 21(10), 1837-1845.

Hafetz, J., \& Miller, V. A. (2010). Child and parent perceptions of monitoring in chronic illness management: A qualitative study. Child: Care, Health and Development, 36(5), 655-662.

Hagel, L. D., Mainieri, A. S., Zeni, C. P., \& Wagner, M. B. (2009). Brief report: Accuracy of a 16-item questionnaire based on the HEADSS approach (QBH-16) in the screening of mental disorders in adolescents with behavioural problems in secondary care. Journal of Adolescence, 32(3), 753-761.

Hanxhiu, A., McKay, K., Singh-Grewal, D., \& Fitzgerald, D. A. (2017). Question 10: Could the burden of care with cystic fibrosis impact on educational outcomes? Paediatric Respiratory Reviews, 23, 56-60.

Higham, L., Ahmed, S., \& Ahmed, M. (2013). Hoping to live a "normal" life whilst living with unpredictable health and fear of death: Impact of cystic fibrosis on young adults. Journal of Genetic Counselling, 22(3), 374-383.

Chrastina, J., Smékalová, L., Maštalíř, J. \& Snopek, P. (2015). Pedagogicko-psychologické aspekty života osob s diagnózou cystická fibróza - dopad do formálního vzdělávání a dalších forem celoživotního vzdělávání. In Sborník př́spěvků z mezinárodní vědecké konference Evropské pedagogické fórum 2015: př́nosy, výzvy, očekávání (s. 97-108). Hradec Králové: Magnanimitas.

Christian, B. J., \& D’Auria, J. P. (1997). The child's eye: Memories of growing up with cystic fibrosis. Journal of Paediatric Nursing, 12(1), 3-12.

Christian, B. J., D’Auria, J. P., \& Moore, C. B. (1999). Playing for time: Adolescent perspectives of lung transplantation for cystic fibrosis. Journal of Paediatric Health Care, 13(3), 120-125. 
Jamieson, N., Fitzgerald, D., Singh-Grewal, D., Hanson, C. S., Craig, J. C., \& Tong, A. (2014). Children's experiences of cystic fibrosis: A systematic review of qualitative studies. Paediatrics, 133(6), 1683-1697.

Kappler, M., \& Griese, M. (2009). Mukoviszidose. Zwischen Normalität und Behinderung. Monatsschrift Kinderheilkunde, 157, 121-128.

Koch, L., Jansen, L., Brenner, H., \& Arndt, V. (2013). Fear of recurrence and disease progression in longterm ( $\geq 5$ years) cancer survivors: A systematic review of quantitative studies. PsychoOncology, 22(1), 1-11.

Lebel, S., \& Devins, G. (2008). Stigma in cancer patients whose behaviour may have contributed to their disease. Future Oncology, 4(5), 717-773.

McDonald, C. M., Haberman, D., \& Brown, N. (2013). Self-efficacy: Empowering parents of children with cystic fibrosis. Journal of Cystic Fibrosis, 12(5), 538-543.

Mighten, J., \& Overend, J. (2016). Cystic fibrosis and school information for schools. Dostupné $\mathrm{z}$ https://www.nuh.nhs.uk/handlers/downloads.ashx?id=26844

Moola, F. J., \& Norman, M. E. (2011). "Down the rabbit hole": Enhancing the transition process for youth with cystic fibrosis and congenital heart disease by re-imagining the future and time. Child: Care, Health and Development, 37(6), 841-851.

Nick, J. A., Chacon, C. S., Brayshaw, S. J., Jones, M. C., Barboa, C. M., St Clair, C. G., ... Sontag, M. K. (2010). Effects of gender and age at diagnosis on disease progression in long-term survivors of cystic fibrosis. American Journal of Respiratory and Critical Care Medicine, 182(5), 614-626.

Oliver, K. N., Free, M. L., Bok, C., McCoy, K. S., Lemanek, K. L., \& Emery, C. F. (2014). Stigma and optimism in adolescents and young adults with cystic fibrosis. Journal of Cystic Fibrosis, 13(6), 737-744.

Pakhale, S., Armstrong, M., Holly, C., Edjoc, R., Gaudet, E., Aaron, S., Tasca, G., Cameron, W., \& Balfour, L. (2014). Assessment of stigma in patients with cystic fibrosis. BMC Pulmonary Medicine, 14, 76.

Palmer, M. L., \& Boisen, L. S. (2002). Cystic fibrosis and the transition to adulthood. Social Work in Health Care, 36(1), 45-58.

Pfeffer, P. E., Pfeffer, J. M., \& Hodson, M. E. (2003). The psychosocial and psychiatric side of cystic fibrosis in adolescents and adults. Journal of Cystic Fibrosis, 2(2), 61-68.

Pizzignacco, T. M., de Mello, D. F., \& de Lima, R. A. (2010). Stigma and cystic fibrosis. Revista Latino-Americana De Enfermagem, 18(1), 139-142.

Quittner, A. L., Goldbeck, L., Abbott, J., Duff, A., Lambrecht, P., Solé, A., ... Barker, D. (2014). Prevalence of depression and anxiety in patients with cystic fibrosis and parent caregivers: Results of The International Depression Epidemiological Study across nine countries. Thorax, 69(12), 1090-1097.

Reid, D. W., Blizzard, C. L., Shugg, D. M., Flowers, C., Cash, C., \& Greville, H. M. (2011). Changes in cystic fibrosis mortality in Australia, 1979-2005. The Medical Journal of Australia, 195(7), 392-395.

Russo, K., Donnelly, M., \& Reid, A. J. M. (2006). Segregation: The perspectives of young patients and their parents. Journal of Cystic Fibrosis, 5(2), 93-99.

Segal, T. Y. (2008). Adolescence: What the cystic fibrosis team needs to know. Journal of the Royal Society of Medicine, 101(1), 15-27. 
Slowík, J. (2007). Speciální pedagogika. Praha: Grada.

Sochocka, L., Noczyńska, A., \& Wojtyłko, A. (2011). Choroba przewlekła w życiu dziecka. Aspekt społeczny oraz psychologiczny na przykładzie Cukrzycy typu 1. Medycyna Środowiskowa, 14(3), 59-63.

Staszak, J.-F. (2008). Other/Otherness. In R. Kitchin \& N. Thrift (Eds.), International encyclopedia of human geography (s. 43-47). Oxford: Elsevier.

Strawhacker, M. T., \& Wellendorf, J. (2004). Caring for children with cystic fibrosis: A collaborative clinical and school approach. The Journal of School Nursing, 20(1), 5-15.

Tluczek, A., Clark, R., McKechnie, A. C., \& Brown, R. L. (2015). Factors affecting parent-child relationships one year after positive newborn screening for cystic fibrosis or congenital hypothyroidism. Journal of Developmental and Behavioral Pediatrics, 36(1), 24-34.

Tong, A., Jones, J., Craig, J. C., \& Singh-Grewal, D. (2012). Children's experiences of living with juvenile idiopathic arthritis: A thematic synthesis of qualitative studies. Arthritis Care \& Research, 64(9), 1392-1404.

Twyman, K. A., Saylor, C. F., Saia, D., Macias, M. M., Taylor, L. A., \& Spratt, E. (2010). Bullying and ostracism experiences in children with special health care needs. Journal of Developmental and Behavioural Paediatrics, 31(1), 1-8.

Willis, E., Miller, R., \& Wyn, J. (2001). Gendered embodiment and survival for young people with cystic fibrosis. Social Science \& Medicine, 53(9), 1163-1174.

\title{
"I'm different, I'm salty... and I'm going to die earlier" (child/pupil with cystic fibrosis in educational environment)
}

\begin{abstract}
Within the present conception of inclusive education, a teacher might give lessons to a diverse group of "different" pupils. Pupils with cystic fibrosis (CF) might also be among them. CF is an incurable, progressive, and terminal illness imposing numerous limitations on everyday activities, including the school activities. The review study aims to analyse, describe, and interpret chosen life spheres of pupils and students with the illness, setting their "otherness/anotherness" in the educational process and environment. Methodological framework involved analytical, synthetic, and interpretative activities in the form of monographic procedure based on researching foreign papers and studies from available databases. Within thematic fields, that could bring about the "otherness/anotherness" in patients with $\mathrm{CF}$, the following themes were covered: CF symptomatology, a community's approach (stigma/stigmatization, victimization, community's attitudes etc.), a person's state subjectivity (experiencing, personal experience, the fear of death, the fear of the illness progression, anxiety, hope, depression, resilience, self-efficacy), support "required" by pupils with $\mathrm{CF}$ (psychological, psychosocial, emotional, relationship, parental, etc.), as well as the educational process specifics. The "otherness/anotherness" described within CF is grounded in the pupils' specific needs following from potential health
\end{abstract}


condition and community's attitudes changes. The current state of our education, respecting the demand for inclusive education, should "settle/wipe off" possible differences and "otherness/anotherness", primarily by means of effective pre-gradual teacher training and continuous educating in the given field.

Key words: otherness/anotherness, cystic fibrosis, limitation, fear, death, education, psychosocial support

\section{Autoři}

Mgr. et Mgr. Jan Chrastina, Ph.D., Univerzita Palackého v Olomouci, Pedagogická fakulta, Ústav speciálněpedagogických studií, Žižkovo náměstí 5, 77140 Olomouc, e-mail: jan.chrastina@upol.cz

Mgr. Tereza Klvaňová, Univerzita Palackého v Olomouci, Pedagogická fakulta, Ústav speciálněpedagogických studií, Žižkovo náměstí 5, 77140 Olomouc, e-mail: tereza.klvanova01@upol.cz

Mgr. Bianka Hudcová, Univerzita Palackého v Olomouci, Pedagogická fakulta, Ústav speciálněpedagogických studií, Žižkovo náměstí 5, 77140 Olomouc, e-mail: bianka.hudcova01@upol.cz 